\title{
Research on the Development and Innovation of College English Translation Teaching Mode in the New Era
}

\author{
Wang Wei \\ Department of Foreign Languages, Dongchang College of Liaocheng University, Shandong, China, 252000
}

Keywords: translation teaching; College English; innovation

\begin{abstract}
Translation teaching is not only an important part of College English teaching, but also a main way to cultivate translation talents. College English translation teaching is an indispensable part of English teaching reform in colleges and universities. The innovation of College English translation teaching model in the new era is not only a new direction of education and teaching, but also an effective extension of traditional teaching. The innovation path of college English translation teaching model in the new era is to optimize the College English curriculum system, introduce the multimedia English communication teaching mechanism, open the students' self-learning model, set up an online platform, develop micro-curriculum resources, and then promote the improvement of College English translation teaching quality.
\end{abstract}

\section{Introduction}

At present, the professional translation talents are very scarce in China, which cannot meet the growing social needs at the present stage. Therefore, colleges gradually pay attention to the training of College Students' English translation ability. In the process of training their English translation ability, in addition to the opening of relevant specialized English courses, it also pays more attention to English translation teaching [1]. Professional English courses can cultivate students' basic translation skills, while translation teaching is a further improvement of College Students' English majors. Therefore, in order to cultivate college students' English translation ability, it is necessary to run through translation teaching in College English teaching. However, the current college English translation teaching is not mature enough, and there are still many deficiencies in the education and teaching practice. In the context of the new era, a foreign language learner must have the translation ability, so the cultivation of translation ability is one of the main goals of College English teaching. The innovation of College English teaching mode cannot leave without the innovation of translation teaching mode dedicated to training students' comprehensive English application ability.

\section{Current Situation of College English Translation Teaching}

\subsection{Disconnection between teaching content and social actual needs}

At present, the teaching materials used in college English translation teaching are relatively old. Over the years, there has not been much change in teaching content, lack of new ideas, lack of innovative ideas that keep pace with the times, resulting in its cannot meet the needs of the development of the international situation. College English translation textbooks only focus on explaining some criteria and theories of English translation, but have little relevance to practical applications. In College English translation textbooks, there are related test questions after class, but only consolidate vocabulary and grammar in the article. The defects in the teaching content make it difficult for the students in the new era to be interested in it, so that the effective learning of the students' English translation can be influenced and the students' quality of English translation cannot be effectively cultivated. 


\subsection{Lack of concern to College English translation teaching}

The biggest limiting factor of traditional teaching is the exam-oriented education thought. The practice of college English translation teaching is also developed around this idea. The purpose of college English teaching is to enable students to achieve outstanding results in the exam, and successfully pass the National College English Test. The more students pass, the better the student's academic performance. However, under the national examination and examination standards, the proportion of university English translation topics is rather small, and there is no practical application of university English translation. Therefore, college English translation teaching has not been given due attention. There are no professional English translations in college English textbooks. Although some textbooks mention a little about the theory and techniques of translation knowledge in college English, the lack of systematic and complete explanation makes college English translation teaching gradually become a vulnerable subject in colleges.

\subsection{Lack of practical platform for College English translation}

The effectiveness of college English translation teaching is manifested in the English translation practice. Therefore, the construction of a college English translation practice platform is an important means for practicing English translation and cultivating English translation elites [2]. However, due to the constraints of various conditions, colleges and universities have not yet established a high-standard, high-efficiency English translation practice platform. Students' English translation practice capabilities have not been able to obtain a large number of effective practical exercises. There is still a big gap in the level of economic development in various parts of the country at present, and the English translation needs of different regions are not the same. There is no effective English translation practice platform, most students can only be restricted by time or space, and the scope of English translation practice is limited to a few surrounding enterprises. The existing practice platform for English translation is only a formalized existence, without practical use value, which leads to the lack of practical social exercise for many students of English translation.

\subsection{Disregarding the cultivation of communicative competence}

There is no examination on students' communicative in the final examination of the college English translation course. In past college English translation teaching, excessive attention was paid to the study of theoretical knowledge, and whether the examination results were excellent or not, neglecting the uniqueness of college English translation teaching, that is, improving the students' English communication skills after mastering the basic English knowledge. Even if the students have a strong grasp of the theoretical knowledge, if they lack practical English communicative competence, it can only be a empty talk, unable to cope with the needs of English translation in the actual work position, and cannot effectively carry out practical work.

\section{The Innovation Strategy of College English Translation Teaching Mode in the New Era}

\subsection{Optimize college English curriculum system.}

Under the new era, teaching mode needs new transformation under the new educational philosophy to better adapt to the needs of the information age. Colleges should establish the latest college English curriculum system, and apply it to the practice of College English teaching as soon as possible, so that students can also carry out professional college English translation learning after mastering the basic knowledge of College English. Colleges and universities can develop English translation and elective courses, such as English newspaper article reading and English and American movie appreciation and other courses, or occasionally hold English translation lectures, etc., to cultivate students' interest in college English translation learning, so that students can not only greatly increase the English vocabulary, and improve the speed of English reading, but also increase accuracy in English translation practice. At the same time, it can also promote more non-English majors to join the college English translation teaching, improve the overall level of students' English learning, and 
promote the development of students' overall quality.

\subsection{Introduce multimedia English communication teaching mechanism.}

The application of multimedia in the teaching of College English translation has changed the traditional mode of teacher speaking and student listening, and students are no longer only mechanically memorizing in the classroom of translation. In the multimedia teaching activities of College English translation, students have highlighted the main position of learning, and become the learners of knowledge, but not the forced knowledge recipients. Many students are not interested in the study of translation theory, but most of them like to watch foreign original sound films. Teachers can play the most popular English movies in class according to the characteristics of the students. There are Chinese subtitles, sounds or English dialogues on the screen. The students will be eager to know how the dialogue in the film is translated, and the students can also feel the difference in the style of Chinese and English words, and learn the skills of English translation. Then, teachers will combine some more formal audio materials to explain the theoretical knowledge of English translation, which will greatly improve the students' interest in the theory of English translation and the initiative of their study, and then improve the level of the teaching of English translation.

\subsection{Develop student self-learning mode.}

In the practice of translation teaching, students should be the main body. College English teachers should aim at cultivating students' self-directed learning abilities and guide students to actively construct independent learning models. The students' learning cannot be separated from the teachers' guidance. The leading role of teachers and the students' main role need to be organically combined to produce good English translation teaching effects. Due to the development of information technology and the emergence of a variety of translation tools, is no longer limited to the classroom. Students can carry out extracurricular autonomous Learning and acquire relevant knowledge in the new teaching environment created by network technology, such as the English translation exchange group. Students can communicate with each other in the group of English translation learning and experience and skills.

\subsection{Develop micro class resources.}

With the rapid development of information technology, colleges and universities need to establish an effective college English translation practice platform to break the limitations of time and space for students' English translation, communication and learning, and provide students with more opportunities for English translation and practical drills. College English courses are developed in order to allow students to apply English to practice on the basis of mastering basic English learning skills, so as to have a certain ability in oral English communication and English writing [3]. This requires students to master English translation skills and skills in addition to the basic knowledge of listening, speaking, reading and writing in English. However, students' English level is very different, and students' understanding of translation teaching content is not the same. Therefore, teachers can develop online teaching resources. Students can choose their own choice according to their own wishes and actual conditions, which can not only take care of the individualized learning needs of each student, but also fully mobilize the autonomy of students' translation learning.

\subsection{Reform objective constraints actively.}

As a teaching and research center and a leading organization, it should be followed by a series of related teaching reforms. First of all, the teaching and research department should clearly write the teaching objectives of the college English translation teaching into the syllabus, so that the teaching objectives of the teachers are clear. College English textbooks should be adjusted according to the requirements of the times, adding translations that meet the requirements of the times and introducing appropriate translation methods [4]. Relevant college English teaching and research departments should pay attention to the cultivation of teachers' translation ability, enhance teachers' post-service education, and train teachers to establish a teaching model centered on cultivating students' translation skills. In the light of the increase in the emphasis of the textbook reform to the translation, 
the teaching institutions in which they belong should adjust the course allocation, which can increase the number of hours and make clear the practice of teaching in translation.

\section{Summary}

In the context of the new era, foreign language translation teaching should improve our translation teaching in terms of curriculum setting, teaching objectives, teaching methods, teaching materials construction, and teaching content, in order to further improve the teaching level. College English teaching belongs to a tedious and systematic project, and involves various aspects such as college English teaching content, ideological concepts, teaching conditions, teaching mode, and construction of teachers. The college English translation teaching under the background of the new era, through the use of modern teaching techniques to train students' autonomous learning ability and language application ability, can cultivate more high-quality English translation talents with international competitiveness and social needs.

\section{References}

[1] Tian Changjing. Discussion on Problems and Solutions of College English Translation Teaching[J]. Journal of Jiamusi Institute of Education, 2011, (4), p.281

[2] Abel, B. English Idioms in the First Language and Second Language Lexicon: A Dual Represent at Ion Approach[J]. Second Language Research, 2013, p.329

[3] Mo Xuqiang, Xie Weiwen. From Teaching Translation to Translation Teaching-An Exploration of Teaching Innovation in Translation from Chinese to Foreign Countries[J]. Journal of Guangdong University of Foreign Studies, 2014, (1), p.83

[4] Huang He. A study of the Stereoscopic Teaching Mode from the Perspective of Open and Interactive Teaching[J]. Journal of Hangzhou Dianzi Keji University (Social Science Edition), 2016, (2), p.69 